Acta Theriologica 40 (2): 163-173, 1995.

PL ISSN 0001-7051

\title{
Reproduction in Eurasian wild boar in central Punjab, Pakistan
}

\author{
Ejaz AHMAD, Joe E. BROOKS, Iftikhar HUSSAIN and M. Hafiz KHAN
}

\begin{abstract}
Ahmad E., Brooks J. E., Hussain I. and Khan M. H. 1995. Reproduction in Eurasian wild boar in central Punjab, Pakistan. Acta Theriologica 40: 163-173.

Five hundred nineteen Eurasian wild boar Sus scrofa (Linneaus, 1758) were collected from March 1987 to July 1990 by shooting in crop and noncrop areas of central Punjab, Pakistan. The male-to-female ratio was 45.7 to 54.3. The age composition consisted of $48 \%$ of the boar being $\leq 12$ months; $29 \%, 13$ to 24 months; and $23 \%>24$ months. Males attained sexual maturity between the ages of 5 to 7 months and females between 4 and 6 months. The testes weights of males changed seasonally, as did the ovarian weights in females. Pregnancies were recorded primarily between February and May; a few were seen in August and September. Almost 32\% of all sexually mature females were visibly pregnant during the study. Most animals were born during the months of April through September. Overall litter sizes averaged 5.7 \pm 2.2 (SD). However, the number of young per litter in females $<12$ months $(4.9 \pm$ 2.0) was less than, but not statistically different from, the number in females $>12$ months $(5.9 \pm 2.2)$. Annual production per female $<24$ months averaged only 1.3 young, while females $>24$ months averaged 3 young. The interaction of photoperiod, summer rainfall, and vegetation development probably determines the timing of the breeding seasons each year.

Department of Fishery and Wildlife Biology, Colorado State University, Fort Collins, Colorado 80523 U.S.A. (EA); U.S. Department of Agriculture/Animal and Plant Health Inspection Service/Animal Damage Control, Denver Wildlife Research Center, P.O. Box 25266, Denver, Colorado 80225-0266 U.S.A. (JEB); Vertebrate Pest Control Laboratory, National Agricultural Research Centre, Islamabad, Pakistan (IH); Department of Entomology, University of Agriculture, Faisalabad, Pakistan (MHK)
\end{abstract}

Key words: Sus scrofa, reproduction, central Pakistan

\section{Introduction}

The Eurasian wild boar Sus scrofa (Linneaus, 1758) is a pest of agriculture in Pakistan (Roberts 1977, Shafi and Khokhar 1986, Brooks et al. 1989). It damages sugarcane, maize, wheat, rice, sorghum, and potatoes, and may be a constraint on the introduction of new crops. Information on reproduction, home range, habitat use, and diet of wild boar is needed to design and implement proper management strategies to reduce crop damage.

There are few studies on the biology and population dynamics of Asian wild boar. Diong (1973) investigated wild boar in Malaysia, and a preliminary study was done in southern Pakistan by Smiet et al. (1979). Accordingly, we initiated 
cooperative studies in 1987 with staff at the University of Agriculture, Faisalabad, to determine the biology, morphometrics, food habits, and movements of wild boar in central Punjab agricultural areas of Pakistan. This study reports on observations of the reproduction in wild boar. The objectives of the study were (1) to determine the age at puberty in both sexes, (2) determine if breeding was seasonal, and if so, to define seasonal changes in male and female breeding capacity, and (3) to determine the average litter size and productivity of wild boar females.

\section{Material and methods}

This study was conducted between March 1987 and July 1990 in crop and noncrop areas in Faisalabad District and immediately adjacent areas in Sheikhupura, Toba Tek Singh, and Jhang Districts in central Punjab (Fig. 1). The main crops in these areas were sugarcane, wheat and maize fields. Noncrop areas consisted of marshy areas supporting growths of Saccharum and Typha species and dry-growth thickets of mesquite Prosopis juliflora, acacia Acacia modesta, and shisham Dalbergia sissoo.

Five hundred nineteen wild boar were collected by hunting and shooting. Wild boar were hunted every week by 1 to 3 hunters with dogs. Most hunting was done during the daytime but some hunts were made at night. All wild boar seen were shot at, regardless of animal size or sex. Hunting was most successful in the late winter, spring and early summer; less so in late summer months. Hence, most females were killed in the months of December (31), January (38), February (25), March (23), May (43), June (20) and July (19). Minimal samples were collected in August (9) and September (8). Reproductive data frequently have been taken from hunted or trapped samples even though the collection of the animals had not been done at random (Johnson et al. 1982, Singer and Ackerman 1981). Each animal was sexed, weighed, and measured. The left or right lower jaws were removed, tagged, and preserved in 5\% formalin. Ages were determined by tooth eruption patterns (Matschke 1967, Briedermann 1971, Kozlo 1975, Hell 1976, Möller 1982) and wear on the third molar (Barrett

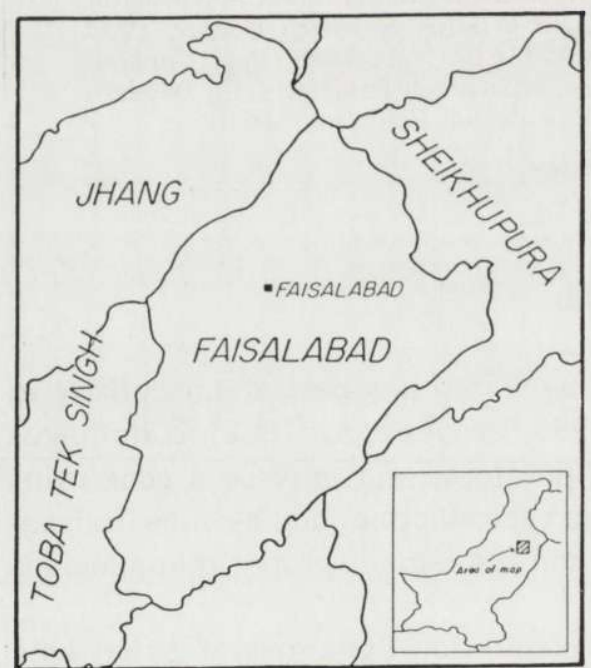

Fig. 1. Faisalabad and adjoining districts in central Punjab.
1978, Iff 1983). Tooth eruption, using Matschke's (1967) and Diong's (1973) schemes were used by several recent authors as a reliable method of aging wild boar or feral pigs up to 26 months (Clarke et al. 1992, Saez-Royuela et al. 1989). The use of wear on the third molar to age animals after 26 months is well-established (Barrett 1978, Iff 1983).

At necropsy, both testes of males were collected and preserved in $5 \%$ formalin. Length $(\mathrm{mm})$, width $(\mathrm{mm})$, and weight $(\mathrm{g})$ were obtained for each testis. The presence of visible tubules in the cauda epididymis was used as the criterion for puberty. The testes weights for each adult male was expressed as grams per kilogram of body weight and plotted against each quarter of the year to determine occurrence of seasonal changes in testicular activity.

The reproductive tract was removed from each female boar and preserved in 5\% formalin. Field observations taken during necropsy included (1) presence or absence of corpora lutea in the ovaries, (2) number of teats, and (3) number of fetuses in each uterine horn. 
Fetuses were preserved in 5\% formalin and were counted, measured, sexed (when possible), and aged (in days) according to crown-rump length (Henry 1968a). These data were used to calculate approximate dates of conception and parturition, based upon an assumed gestation period of 115 days (Henry 1968b). Variation in litter size by age class of the female was examined, and the correlation of age and body weight of the females with the number of fetuses was tested.

Ovaries were weighed, sectioned at 1.5 - $\mathrm{mm}$ intervals, and examined under a dissecting microscope for follicles, corpora lutea, and corpora albicantia. The presence of corpora lutea and the technique of back-dating ages of fetuses were used to determine age of puberty for females. Data on littering activity were collected by aging and forward-dating fetuses and aging and back-dating animals $<6$ months old.

\section{Results}

\section{Sex and age structure}

Five hundred nineteen wild boar (237 males and 282 females) were collected. The age composition of 493 animals (26 of the total were of unknown age) was $48 \%$ from 1 to 12 months, $29 \%$ from 13 to 24 months, and $24 \%>24$ months (Table 1 ).

Table 1. Age composition and sex ratio in wild boar collected from central Punjab.

\begin{tabular}{lccc}
\hline Age (months) & Males & Females & Males/100 females \\
\hline Fetuses & 84 & 83 & 101 \\
$0-4$ & 29 & 28 & 104 \\
$5-8$ & 63 & 90 & 70 \\
$9-12$ & 10 & 14 & 71 \\
$13-24$ & 66 & 75 & 88 \\
$25-36$ & 32 & 35 & 91 \\
$>36$ & 26 & 25 & 104 \\
Totals, aged & 226 & 267 & 84 \\
Unknown age & 11 & 15 & \\
Totals & 237 & 282 & 84 \\
\hline
\end{tabular}

The male to female sex ratio was equal between birth and 4 months, decreased between 5 and 12 months, and then increased again between 1 and $>3$ years.

\section{Puberty}

Both sexes were capable of breeding during their first year. We found a few males with visible tubules in the cauda epididymis as early as 4 to 5 months of age. However, sexual maturity began at 6 months when over $50 \%$ of the males had visible tubules; most males were physiologically capable of breeding at 7 to 8 months. Testis weights for several age groups are given in Table 2. 
Table 2. Mean testis weight (without epididymis) in male wild boar collected from 1987-1990.

\begin{tabular}{lcc}
\hline Age (months) & $\begin{array}{c}\text { Number of } \\
\text { animals examined }\end{array}$ & $\begin{array}{c}\text { Testis weight (g) } \\
\bar{x} \pm \mathrm{SD}\end{array}$ \\
\hline $4-5$ & 25 & $7.9 \pm 7.9$ \\
$6-12$ & 39 & $51.0 \pm 31.8$ \\
$13-18$ & 33 & $67.9 \pm 27.6$ \\
$19-24$ & 23 & $127.3 \pm 51.9$ \\
$>24$ & 51 & $161.6 \pm 56.8$ \\
\hline
\end{tabular}

Table 3. Presence of corpora lutea in young female wild boar, 1987-1990.

\begin{tabular}{lrc}
\hline Age (months) & $n$ & $\begin{array}{c}\text { Corpora lutea } \\
\text { present }\end{array}$ \\
\hline $0-2$ & 8 & 0 \\
$2-4$ & 4 & 0 \\
$4-5$ & 10 & 5 \\
$5-6$ & 10 & 8 \\
$6-7$ & 12 & 12 \\
\hline
\end{tabular}

We found ovulating females at 4 to 5 months of age (Table 3 ). Similarly in the 1988 breeding season, 7 of the 30 pregnant females were aged 6 to 12 months, indicating that ovulation occurred even earlier than 6 months in some animals.

\section{Breeding season}

Mating activity began at different times each year. In 1987, it started in late December and continued into early March 1988. It began again at the end of October 1988 and continued into early March 1989. In 1990, breeding began the first week of January and continued into the first week of April.

Pregnant animals were collected from February through September 1988, from January through September 1989, and from February through June 1990 (Fig. 2). Littering dates, extrapolated from aged fetuses and back-dated young animals, are given in Fig. 3. A breeding effort appeared in the fall of 1987, the first year of the study. The breeding pattern in 1988 appeared to be basically bimodal, with peaks in spring and late summer; the effort in 1989 appeared to be unimodal,

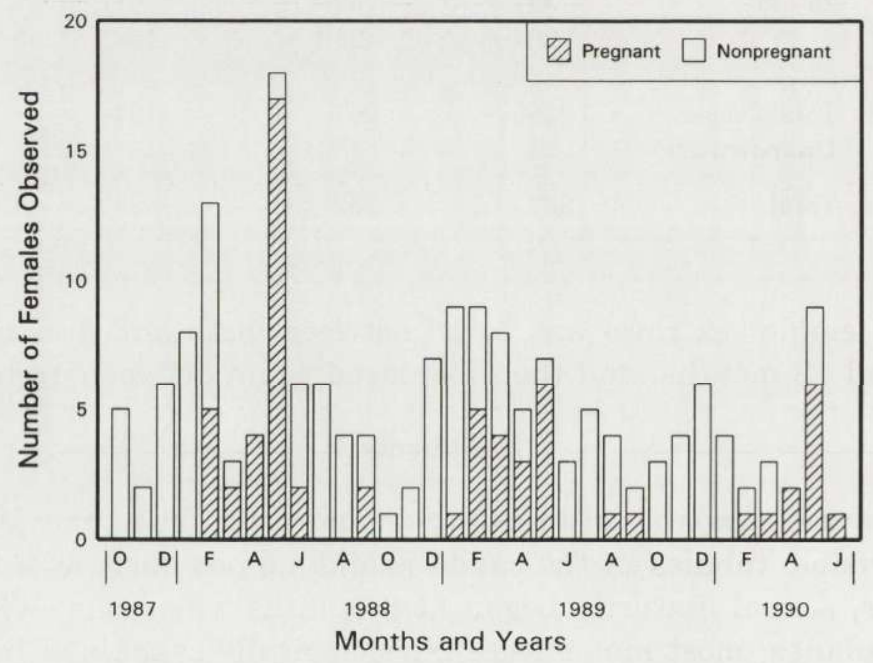

Fig. 2. Occurrence of visible pregnancies in adult wild boar. 


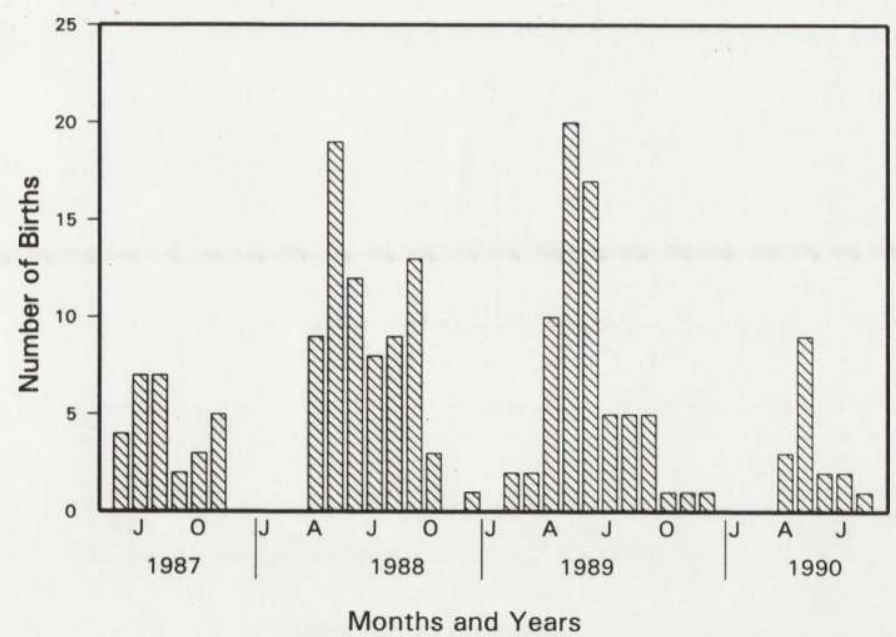

Fig. 3. Distribution of births determined from aged fetuses and young animals $<6$ months, 1987-1990.

with a spring peak only. Most births occurred in the months of April through September, with a few animals born in October and November. The birthing seasons each year were separated by a 3 - or 4 -month nonbirthing period in the fall and winter months.

Seasonal changes in the adjusted testes weights in the male wild boar are given in Fig. 4. In each year, the lowest weights occurred between July and September, and the peak weights were between January and March. The differences between

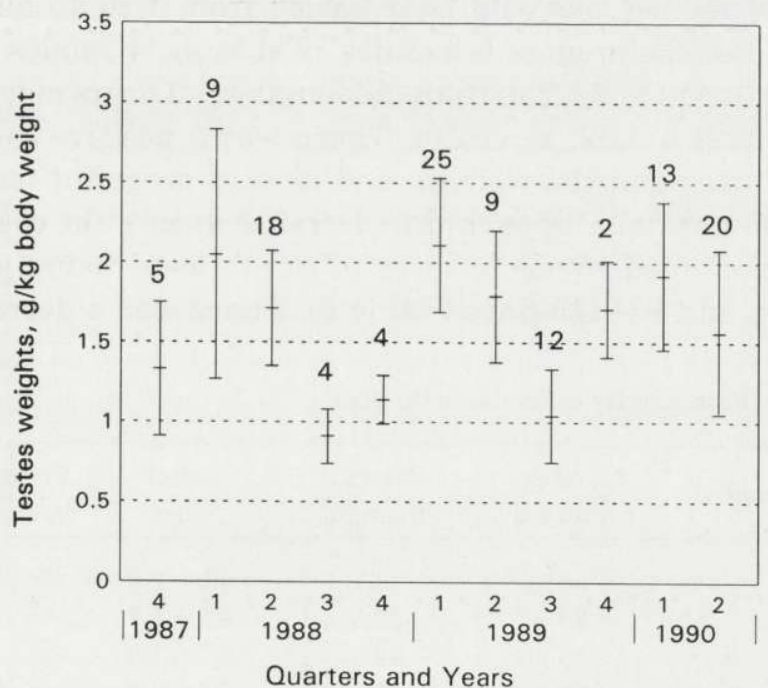

Fig. 4. Seasonal changes in testes weights (adjusted for body weight) of male wild boar (means \pm SD), sample size above the bar. 


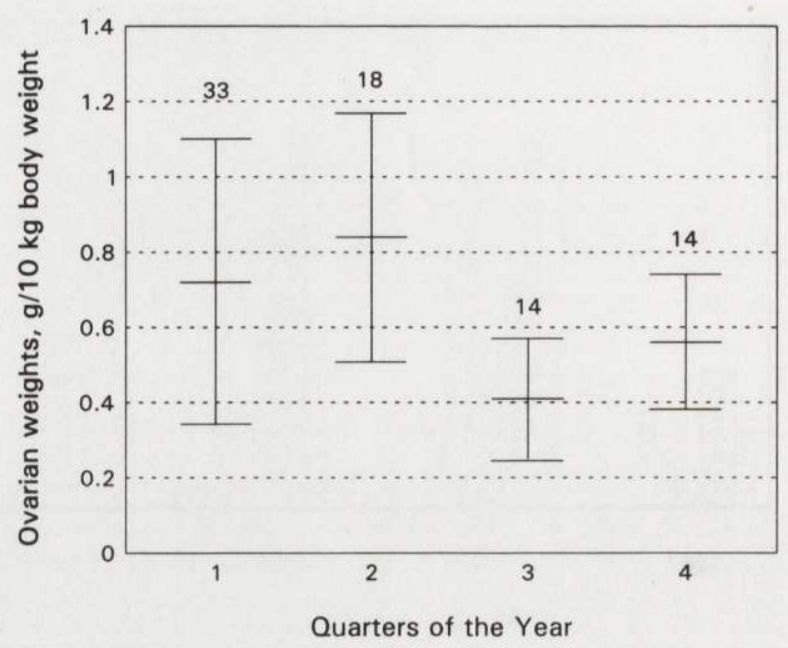

Fig. 5. Seasonal changes in ovarian weights (adjusted for body weight) of females (means \pm SD), sample size above the bar.

the late summer quarters and the winter-spring quarters were significant ( $p=$ 0.01 ) each year.

Ovarian weights of females also fluctuated seasonally $(t=4.53, p=0.001)$. The lowest weights were seen from July through September (Fig. 5), and the peak weights were observed in April through June.

\section{Litter size}

The number of fetuses per wild boar varied from 1 to 10 and averaged $5.7 \pm$ 2.2 (SD) among the 61 pregnant females (Table 4). Females $<1$ year of age averaged smaller litters $(4.9 \pm 2.0)$ than did females $>2$ years old, but the difference was not significant $(t=1.52, p>0.10)$. There was a positive correlation between the number of fetuses and the weights and ages of pregnant females.

Litter size in female boar appeared to decrease during the course of pregnancy. Litter size was examined by age classes of the fetuses, using groups aged 0-60 days, 61-90 days, and 91-115 days (Table 5). There was a decrease from a mean

Table 4. Productivity of female wild boar.

\begin{tabular}{lcccc}
\hline Age (months) & $\begin{array}{c}\text { Number } \\
\text { examined }\end{array}$ & $\begin{array}{c}\text { Percent } \\
\text { pregnant }\end{array}$ & $\begin{array}{c}\text { Litter } \\
\text { size }\end{array}$ & $\begin{array}{c}\text { Production of } \\
\text { young/female }\end{array}$ \\
\hline $6-12$ & 58 & 24.1 & $4.9 \pm 2.0$ & 1.2 \\
$13-24$ & 75 & 28.0 & $4.7 \pm 1.7$ & 1.3 \\
$25-36$ & 35 & 42.9 & $6.7 \pm 1.9$ & 2.9 \\
$>36$ & 25 & 44.0 & $7.1 \pm 2.3$ & 3.1 \\
Totals & 193 & 31.6 & $5.7 \pm 2.2$ & 1.8 \\
\hline
\end{tabular}


of 6.1 fetuses in early pregnancy to 5.4 in late pregnancy, representing an $8.9 \%$ loss. Likewise, ovarian analysis of 17 pregnant females revealed 104 corpora lutea of pregnancy and a corresponding fetus count of 87 , indicating an intrauterine loss of $16 \%$ of the shed ova.
Table 5. Age of fetuses and mean litter size.

\begin{tabular}{llc}
\hline $\begin{array}{l}\text { Fetus age } \\
\text { (days) }\end{array}$ & $n$ & $\begin{array}{c}\text { Litter size } \\
(\bar{x} \pm \mathrm{SD})\end{array}$ \\
\hline $0-60$ & 13 & $6.1 \pm 2.0$ \\
$61-90$ & 20 & $5.7 \pm 2.0$ \\
$91-115$ & 27 & $5.4 \pm 2.4$ \\
\hline
\end{tabular}

Teats

The number of visible teats ranged from 3 to 10 per female and averaged 8.3 \pm 0.9 (SD) in 209 females. Either 8 or 10 teats were found in $90 \%$ of the females, which is less than the 16 usually found in domestic breeds (Plum 1938, Smith et al. 1938) and less than the 11.9 to 12.6 observed by Barrett (1978) in feral hogs in California.

\section{Age and productivity of female}

The productivity of several age classes of female wild boar is detailed in Table 4 . Young-of-the-year females accounted for $23 \%$ of all observed pregnancies, but produced only 1.2 young/female. Yearling females accounted for $34 \%$ of pregnancies, but again, because of small litters, they produced only 1.3 young/female. Females 2 years or older accounted for the greatest production, 3.0 young/female. The highest percentage of pregnancies and largest litter sizes occurred in this age group. Overall production ran 1.8 young/female.

\section{Discussion}

The sex ratio of $46 \%$ males to $54 \%$ females among the collected animals is similar to that reported by Conley et al. (1972) who found a $47 \%$ male to $53 \%$ female ratio in hunter-harvested feral hogs on the Tellico Wildlife Management Area in Tennessee. However, it is different from that reported by Johnson et al. (1982) of 52\% males to $48 \%$ females in European wild boar in Tennessee. Fox and Pelton (1977) and Sweeney et al. (1979), reporting on European wild boar and feral hogs, respectively, also found more males than females. Barrett (1978) found the sex ratio of young ( $<12$ months) feral hogs was 50 males to 50 females, while in adults the ratio was 46 males for every 54 females. In our study, the ratio in young (< 12 months) was 44 males to 56 females; in adults it was 48 males for every 52 females, which is in agreement with Barrett's findings in California.

A female-skewed sex ratio in our collection should not affect productivity, since females generally breed with numerous males while in estrus (Barrett 1978). It may imply that there was a higher mortality among males than females.

The age structure we observed $(48 \%<12$ months, $29 \%$ yearlings, $23 \%>24$ months) was similar to Barrett's (1978) age structure in feral hogs in California 
and to Johnson's et al. (1982) findings in wild boar in the Great Smoky Mountains. From the age structures in these studies, it appears that mortality is very high in feral hogs and wild boar in both the United States and Pakistan. Maximum longevity in the Pakistan animals is unknown, since we could not age animals by molar wear beyond 6 years.

Male wild boar in Pakistan come into sexual maturity at 5 months of age. When 7 to 8 months old, 11 out of 16 wild boar were found with visible tubules in the cauda epididymis. Testis weights at this age averaged $46 \mathrm{~g}(n=16)$. These findings are in agreement with Sweeney et al. (1979), who found that male feral hogs reached sexual maturation between 5 to 7 months. Barrett (1978) found that male feral hogs in California attempted to breed when 6 months old. Other observers reported later sexual maturity in European wild boar, occurring between 7.5 to 12 months in Tennessee (Johnson et al. 1982). Weights of testes in Pakistan wild boar are in agreement with those found by Johnson et al. (1982) in Tennessee.

One female wild boar bred as early as 4 months, while 5 others bred when 5 months old. Corpora lutea were first seen at 4 to 5 months in half the sample. In this respect Pakistan wild boar differ from wild boar in Europe, which generally breed as yearlings (18 to 21 months) (Sludskii 1956, Haber 1969). In Tennessee, Johnson et al. (1982) found that European wild boar females bred between 5 and 8 months. Feral hogs apparently breed at a later age: Sweeney et al. (1979) reported that feral hogs bred at 10 months in South Carolina, Barrett (1978) reported breeding between 6 and 8 months in feral sows in California, and Conley et al. (1972) reported an average breeding age of 9.2 months in 9 captive feral sows. Domestic sows can breed as early as 3 months of age, but first successful breeding normally occurs between 6 to 7 months of age. Female wild boar in Pakistan more closely resemble domestic sows than female feral hogs, but the difference is slight.

The fetal litter size, averaging 5.7 for 61 females, was higher than that reported for the wild boar in Germany (Briedermann 1971), France (Mauget 1972, Aumaitre et al. 1984), and Spain (Saez-Royuela and Telleria 1987), but approximates that observed in other studies from Germany (Stubbe and Stubbe 1977), Austria (Martys 1982), and France (Mauget 1982). The mean litter size of European wild boar in the United States has varied from 3.0 (Johnson et al. 1982) to 4.8 (Henry 1966, Conley et al. 1972). Feral hogs in the United States appear to have larger litters than U.S. wild boar: Barrett (1978) found 5.6 young/litter in California, Diong (1982) reported 5.9 in Hawaii, and Sweeney et al. (1979) found 7.4 in South Carolina.

The young-of-the-year females made a significant contribution to the population in our study. Representing only $23 \%$ of all pregnant females in the three breeding seasons, they would have produced 69 young, or $20 \%$ of the total production of young. For comparison, the older females (77\%) could have produced 276 young, or $80 \%$ of the total.

The most productive age classes are females aged $>25$ months because litter size increased appreciably in the older females and the frequency of pregnancy 
was greater than $40 \%$. These two factors resulted in a production of 2.9 and 3.1 young/litter for 2- and 3-year old (or older) females, respectively.

Pakistan wild boar exhibited seasonal breeding patterns. Conceptions occur mainly during the winter months of December into the following March, occasionally followed by another short mating period in May and June (as evidenced by animals born in September and October). Most animals were born between the months of April through September. Smiet et al. (1979) also found two pregnant females from lower Sind, Pakistan, one of which would have littered in March and the other in the second half of April. These patterns of a winter mating period and spring-summer births are similar to those reported by Mauget (1982) from France. Diong (1973) noted that of 165 females killed by hunters from early February to early May in western Malaysia, 56 (34\%) were pregnant, indicating a winter/spring breeding season there.

These same general farrowing periods are reported for the European wild boar by Briedermann (1971) in the ex-German Democratic Republic and by Aumaitre et al. (1984) in France. The patterns of farrowing in the European wild boar in the United States are somewhat different. Conley et al. (1972) reported that in Tennessee farrowing occurred in two peaks in January and May. Johnson et al. (1982) found that in the Great Smoky Mountains National Park farrowing occurred year-round, but a peak was seen in November through January and another in May.

Seasonality in the testes weights of male wild boar was not reported in other studies. Sweeney et al. (1979) found no correlation between season and weight or volume of testes. Johnson et al. (1982) found no seasonal differences when total testes weight, expressed as a percentage of the whole body weight, was plotted against the months of the year. We found ovarian weights changed seasonally also.

Mauget (1982) has shown that wild boar breeding appeared to be photoperiodic. Anestrus increased in late spring, as daylight increased, and approached $100 \%$ in the sows by summer. The onset of the subsequent breeding season was also controlled by the availability of the acorn crop in the forest in the autumn. In years of good acorn production, breeding started in October/November, but it was delayed until December/January in years of poor acorn production. Baber and Coblenz (1987) concluded that the interaction of diet and photoperiod controlled the seasonality of breeding in feral pigs on Santa Catalina Island, California.

Photoperiod and rainfall would be the most probable environmental factors regulating breeding in wild boar in Pakistan. In October 1988, breeding activity followed above average rainfall in July, August, and September. This summer monsoon rainfall apparently provided better forage conditions for wild boar. The next summer season was below normal for rainfall, and breeding did not start until the first week of January 1990.

The major breeding season of wild boar in Pakistan coincides with the planting, growth, and maturation of the wheat crop. Wheat is planted in late November 
into late December, and harvesting takes place in late April to early May. Stomach contents of wild boar from March through June contain mainly wheat grains (J. E. Brooks et al., unpubl.). Young animals appear during the period that maize and sorghum are maturing and, in late summer, sugarcane fields provide sanctuaries for all age groups of wild boar.

The Eurasian wild boar in Pakistan is a seasonal breeder, yet it has a high reproductive potential for a large mammal. This capability is because (1) both sexes come into puberty at the age of 5 to 6 months, (2) females can breed during the year of their birth, and (3) females average litters of 5 to 6 young. The wild boar is considered a major agricultural pest because of its large size and its high visibility, because its production of young coincides with the ripening and harvest of the wheat crop, and because it hides in, and damages, the sugarcane crop following the major and minor breeding efforts.

Acknowledgements: We thank R. Khan, C. Z. Khan, M. A. Shah, and M. Mazhar for their help in shooting and collecting the wild boar. Special thanks are due to S. Masih for field and laboratory assistance in collecting animal tissues. We appreciate the laboratory assistance of M. Ilyas and L. Wahla for help in aging the jaws. We express our sincere appreciation to R. Bruggers, J. Keith, M. Tobin, and P. Woronecki, Denver Wildlife Research Center, for their critical review of the manuscript. This work was supported with funds provided by the U.S. Agency for International Development under the project "Food Security Management, Vertebrate Pest Control, PASA IPK-0491-P-IF-5017-05". We appreciate the support of the National Agricultural Research Centre and the Pakistan Agricultural Research Council, Islamabad, for providing laboratory and office space.

\section{References}

Aumaitre A., Quere J. P. and Peiniau J. 1984. Effect of environment on winter breeding and prolificacy of the wild sow. Symposium international sur le sanglier, Toulouse (France): 69-78. [In French with English summary]

Baber D. W. and Coblenz B. E. 1987. Diet, nutrition and conception in feral pigs on Santa Catalina Island. Journal of Wildlife Management 51: 306-317.

Barrett R. H. 1978. The feral hog on the Dye Creek Ranch, California. Hilgardia 46(9): 283-355.

Briedermann L. 1971. Zur Reproduktion des Schwarzwildes in der Deutschen Demokratischen Republik. Beiträge zur Jagd- und Wildforschung 7: 169-186.

Brooks J. E., Ahmad E., Hussain I. and Khan M. H. 1989. The agricultural importance of the wild boar (Sus scrofa L.) in Pakistan. Tropical Pest Management 35: 278-281.

Clarke C. M. H., Dzięciołowski R. M., Batcheler D. and Frampton C. M. 1992. A comparison of tooth eruption and wear and dental cementum techniques in age determination of New Zealand feral pigs. Wildlife Research 19: 769-777.

Conley R. H., Henry V. G. and Matschke G. H. 1972. European hog research project W-34, final report. Tennessee Wildlife Resource Agency, Nashville: 1-259.

Diong C. H. 1973. Studies of the Malayan wild pig in Perak and Johore. Malayan Nature Journal 26: $120-151$.

Diong C. H. 1982. Population biology and management of the feral pig (Sus scrofa L.) in Kipahulu Valley, Maui. Ph D thesis, University of Hawaii, Honolulu: 1-408.

Fox J. R. and Pelton M. R. 1977. An evaluation of control techniques for the European wild hog in the Great Smoky Mountains National Park. [In: Research and management of wild hog populations, G. W. Wood, ed]. Belle W. Baruch Forest Science Institute, Georgetown, S.C.: 56-66. 
Haber A. 1969. [Wild boar]. Państwowe Wydawnictwo Rolnicze i Leśne, Warszawa: 1-216. [In Polish]

Hell P. 1976. Vergleich der Altersbestimmung des Schwarzwildes nach Jahresringen im Zahnzement und nach der Abnützung des Gebisses. Folia Venatoria 5-6: 57-66.

Henry V. G. 1966. European wild boar hunting season recommendations based on reproductive data. Proceedings of the Southeast Association of Game and Fish Commissioners 20: 139-145.

Henry V. G. 1968a. Fetal development in European wild hogs. Journal of Wildlife Management 32: 966-970.

Henry V. G. 1968b. Length of estrous cycle and gestation in European wild hogs. Journal of Wildlife Management 32: 406-408.

Iff U. 1983. Zahnentwicklung und Altersbestimmung beim Schwarzwild. Wild und Hund 86(11): 26-30.

Johnson K. G., Duncan R. W. and Pelton M. R. 1982. Reproductive biology of European wild hogs in the Great Smoky Mountains National Park. Proceedings of the Annual Conference of the Southeast Association of Fish and Wildlife Agencies 36: 552-556.

Kozlo P. 1975. [Wild boar]. Verlag Uradshai, Minsk: 1-223. [In Russian]

Martys M. 1982. Gehegebeobachtungen zur Geburts- und Reproduktionsbiologie des europäischen Wildschweines (Sus scrofa L.). Zeitschrift für Säugetierkunde 47: 100-113.

Matschke G. H. 1967. Aging European wild hogs by dentition. Journal of Wildlife Management 31: 109-113.

Mauget R. 1972. Observations sur la reproduction du sanglier (Sus scrofa L.) a l'etat sauvage. Annales de Biologie Animale Biochimie Biophysique 12: 195-202.

Mauget R. 1982. Seasonality of reproduction in the wild boar. [In: Control of pig reproduction. D. J. A. Cole and G. R. Foxcroft, eds]. Butterworths Scientific Publications, London: 509-526.

Möller D. 1982. Untersuchungen zur Altersbestimmung erlegten älteren Schwarzwildes. Forschungsbericht, Forstinstitut Eberswalde.

Plum M. 1938. Inheritance of mammae in swine, a character involving partly symmetrical organs. Hereditas 24: 216-230.

Roberts T. J. 1977. The mammals of Pakistan. Ernest Benn, London: 1-361.

Saez-Royuela C. and Telleria J. L. 1987. Reproductive trends of the wild boar (Sus scrofa) in Spain. Folia Zoologica 36: 21-25.

Saez-Royuela C., Gomariz R. P. and Telleria J. L. 1989. Age determination of European wild boar. Wildlife Society Bulletin 17: 326-329.

Shafi M. M. and Khokhar A. R. 1986. Some observations on wild boar (Sus scrofa) and its control in sugarcane areas of Punjab, Pakistan. Journal of the Bombay Natural History Society 83: 63-67.

Singer F. J. and Ackerman B. B. 1981. Food availability, reproduction and condition of European wild boar in Great Smoky Mountains National Park. National Park Service Research/Resources Management Report No. 43, Gatlinburg, Tennessee: 1-59.

Sludskii A. A. 1956. [The wild boar: its morphology, ecology, and epizootiological importance]. Izadatel'stvo Akademii Nauk Kazachskoi SSR, Alma Ata: 1-220. [In Russian]

Smiet A. C., Fulk G. W. and Lathiya S. B. 1979. Wild boar ecology in Thatta District: a preliminary study. Pakistan Journal of Zoology 11: 295-302.

Smith A. D. B., Robison O. J. and Bryant D. M. 1938. The genetics of the pig. Bibliographia Genetica 12: $1-160$.

Stubbe W. and Stubbe M. 1977. Vergleichende Beiträge zur Reproduktion und Geburtsbiologie von Wild- und Hausschwein Sus scrofa L. Beiträge zur Jagd- und Wildforschung 10: 153-179.

Sweeney J. M., Sweeney J. R. and Provost E. E. 1979. Reproductive biology of a feral hog population. Journal of Wildlife Management 43: 555-559.

Received 11 April 1994, accepted 21 February 1995. 